\title{
Pertussis immunisation and serious acute neurological illness in children
}

\author{
D L MILLER, E M ROSS, R ALDERSLADE, M H BELLMAN, N S B RAWSON
}

\begin{abstract}
The first 1000 cases notified to the National Childhood Encephalopathy Study were analysed. The diagnoses included encephalitis/encephalopathy, prolonged convulsions, infantile spasms, and Reye's syndrome. Eightyeight of the children had had a recent infectious disease, including 19 with pertussis.

Only 35 of the notified children (3.5\%) had received pertussis antigen within seven days before becoming ill. Of 1955 control children matched for age, sex, and area of residence, $34(1.7 \%)$ had been immunised with pertussis vaccine within the seven days before the date on which they became of the same age as the corresponding notified child. The relative risk of a notified child having had pertussis immunisation within that time interval was $2.4(p<0.001)$. Of the 35 notified children, 32 had no previous neurological abnormality. A year later two had died, nine had developmental retardation, and 21 were normal.
\end{abstract}

A significant association was shown between serious neurological illness and pertussis vaccine, though cases were few and most children recovered completely.

Department of Community Medicine, Middlesex Hospital Medical School, Horace Joules Hall, Central Middlesex Hospital, London NW10 7NS

D L MILLER, FRCP, FFCM, professor of community medicine

E M ROSS, MD, FRCP, senior lecturer in child health and community medicine

R ALDERSLADE, MA, BM, lecturer in community medicine (now medical officer, Department of Health and Social Security, Alexander Fleming House, London SE1)

M H BELLMAN, MB, MRCP, lecturer in child health

N S B RAWSON, MSC, Fss, statistician (now senior research fellow, Drug Surveillance Research Unit, University of Southampton)

\section{Introduction}

We report findings from the first 1000 cases notified during an investigation of serious neurological illnesses in early childhood and their relation to immunisation with vaccine containing pertussis antigen.

Although there have been reports of neurological illness after pertussis immunisation since 1933, ${ }^{1}$ none has been based on established epidemiological methods using relevant controls. The inconclusive nature of this evidence has resulted in much debate in the media, particularly in Britain, ${ }^{2}{ }^{3}$ and left doctors and parents anxious and confused about the safety of the vaccine. The national uptake of pertussis immunisation dropped from over $80 \%$ in 1974 to $31 \%$ in 1978 , with only $9 \%$ of children being immunised in part of Wales. ${ }^{4}$ These low rates coincided with the largest epidemic of pertussis for 20 years.

The questions Does pertussis vaccine cause brain damage? and, if so, How often ? are difficult to answer because the neurological disorders allegedly caused by pertussis vaccine are apparently most uncommon and have no unique clinical features. ${ }^{5}$

Moreover, children are immunised at an age when the incidence of serious neurological illnesses, associated with many aetiological factors, is high. There is thus a risk that these conditions may be inappropriately attributed to immunisation. This difficulty makes it essential to compare the immunisation history of affected children with that of a group of matched controls in order to interpret any association.

The National Childhood Encephalopathy Study was begun after a request by the Joint Committee on Vaccination and Immunisation for further evidence. A case-control approach was chosen for its relative simplicity, despite the disadvantage that unknown factors affecting the selection of controls might influence their chance of recent immunisation. The alternative, a cohort approach, was rejected because extremely large numbers of immunised and unimmunised children would be required to show any significant difference between their subsequent 
rates of serious neurological illnesses. The study was confined to children admitted to hospital and excluded those with mild or transitory neurological symptoms.

\section{Sources of data and methods}

We aimed to collect as many cases as quickly as possible by identifying all children in England, Scotland, and Wales with specified serious acute neurological illnesses, including those possibly caused by pertussis immunisation. These included encephalitis or encephalopathy, unexplained coma, convulsions lasting more than 30 minutes or followed by persistent neurological complications, infantile spasms, and Reye's syndrome. Any such illnesses severe enough to be associated with the risk of subsequent permanent brain damage were thought likely to lead to admission to hospital. All consultant paediatricians, infectious disease specialists, and neurosurgeons were asked to notify the study of any child aged 2 months to the third birthday admitted under their care during 1 July 1976 to 30 June 1979 with an illness satisfying the study criteria.

Details of the acute illness were requested from the notifying consultant. Children who recovered before discharge or within 15 days were followed up for one year by letters to the consultant and the general practitioner. Those with a neurological abnormality on discharge or 15 days after admission were examined at home by a study paediatrician at least twice during the next year. Information on children who died from acute neurological illness was obtained from death certificates.

Two control children matched for sex, age, and area of residence were selected for each case by the local specialist in community medicine for child health from either the current register of children eligible for immunisation or the birth register.

The immunisation history of each notified child and control was obtained independently from the specialist in community medicine and the general practitioner. Discrepancies in the information supplied were the subject of further enquiries. ${ }^{6}$

Case and control children were visited at home to seek factors in their personal, family, and environmental histories which may have predisposed to neurological illness. The date of onset of the neurological illness for each case was decided only after a review of all available information.

TABLE I-Categories of outcome 15 days after admission or at discharge (whichever occurred first)

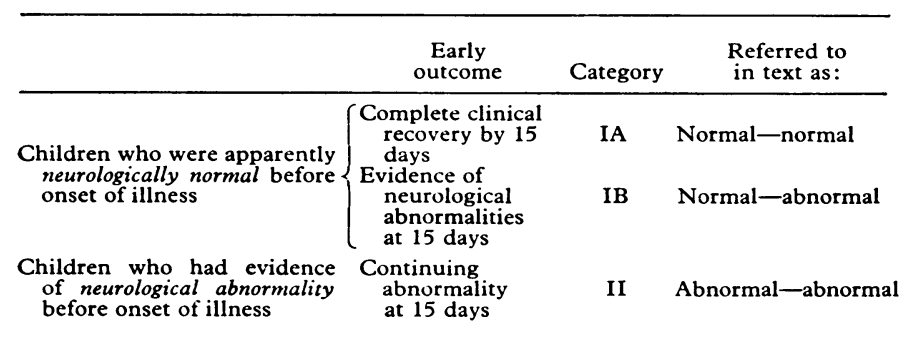

Three categories of early outcome were defined according to the child's condition 15 days after admission or at discharge, whichever was sooner (table I). Late outcome refers to the child's condition on follow-up at least 12 months later, as reported either by letter from the local doctors or from the study paediatrician's examination.
TABLE III-History of acute infectious disease within four weeks before admission (data not available in 76 cases)

\begin{tabular}{|c|c|c|c|c|c|c|c|c|}
\hline \multirow{3}{*}{$\begin{array}{l}\text { Infectious } \\
\text { disease }\end{array}$} & \multicolumn{6}{|c|}{ Category } & & \\
\hline & \multicolumn{2}{|c|}{$\begin{array}{c}\text { IA } \\
\text { (normal- } \\
\text { normal; } \\
\mathbf{n}=\mathbf{4 4 3} \text { ) }\end{array}$} & \multicolumn{2}{|c|}{$\begin{array}{c}\text { IB } \\
\text { (normal- } \\
\text { abnormal; } \\
\mathbf{n}=286 \text { ) }\end{array}$} & \multicolumn{2}{|c|}{$\begin{array}{l}\text { II } \\
\text { (abnormal- } \\
\mathbf{n}=195)\end{array}$} & \multicolumn{2}{|c|}{$\begin{array}{c}\text { Total } \\
(\mathrm{n}=924)\end{array}$} \\
\hline & No & $\%$ & No & $\%$ & No & $\%$ & No & $\%$ \\
\hline $\begin{array}{l}\text { Measles .. } \\
\text { Rubella . } \\
\text { Chickenpox } \\
\text { Mumps . } \\
\text { Whooping cough } \\
\text { Rash } \\
\text { None of above : }\end{array}$ & $\begin{array}{r}16 \\
4 \\
2 \\
3 \\
10 \\
11 \\
397\end{array}$ & $\begin{array}{r}4 \\
1 \\
<1 \\
1 \\
2 \\
2 \\
2 \\
90\end{array}$ & $\begin{array}{r}9 \\
4 \\
2 \\
5 \\
7 \\
6 \\
253\end{array}$ & $\begin{array}{r}3 \\
1 \\
1 \\
2 \\
2 \\
2 \\
88\end{array}$ & $\begin{array}{r}3 \\
0 \\
0 \\
0 \\
2 \\
4 \\
186\end{array}$ & $\begin{array}{r}2 \\
0 \\
0 \\
0 \\
1 \\
2 \\
95\end{array}$ & $\begin{array}{r}28 \\
8 \\
4 \\
8 \\
19 \\
21 \\
836\end{array}$ & $\begin{array}{r}3 \\
1 \\
<1 \\
1 \\
2 \\
2 \\
90\end{array}$ \\
\hline
\end{tabular}

TABLE IV-History of infectious disease present at time of admission (in 76 cases data not available)

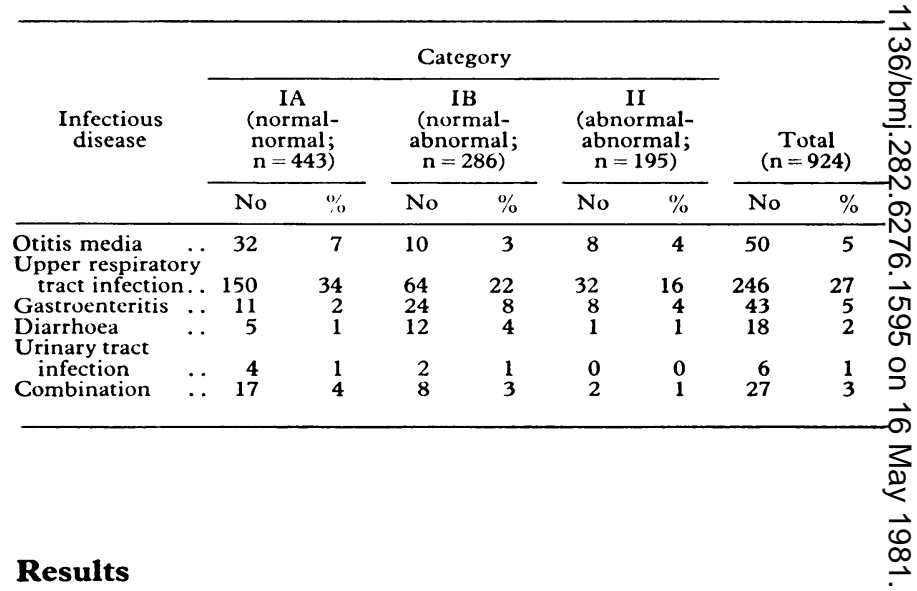

A total of 1182 children were included in the study during theo three years. This report concerns the first 1000 cases notified.

\section{REGIONAL DISTRIBUTION}

Cases were notified from all parts of England, Scotland, and Wales $\stackrel{3}{-}$ Some hospital units did not participate until the study had been if progress for several months, but there was no known non-participat ing unit during the second and third years. No noticeable clusterings of cases in any NHS region was found.

\section{SEX AND AGE}

There was no significant difference in the sex distribution of children notified. Table II shows the distribution of cases by the age at onset of the illness. Most of the children were under 18 monthos of age. The median ages of the children in categories IA, IB, and IE. were $13.3,7.5$, and 6.4 months, respectively. Retrospective inquirn showed that 14 of the children in category II began to have symptom\$ in the neonatal period.

TABLE II-Age distribution of notified infants at onset of symptoms (figures are numbers of infants)*

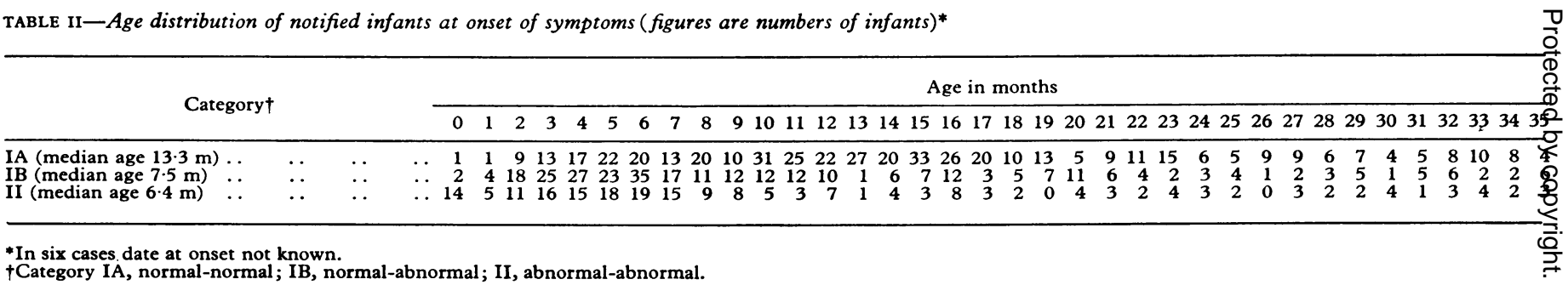


Factor in past medical history

Proportion of cases in each category*

\begin{tabular}{|c|c|c|c|c|c|c|c|c|c|}
\hline \multicolumn{2}{|l|}{ Factor in past medical history } & \multicolumn{2}{|c|}{$\begin{array}{c}\text { Category IA } \\
\text { (normal-normal) }\end{array}$} & \multicolumn{2}{|c|}{$\begin{array}{c}\text { Category IB } \\
\text { (normal-abnormal) }\end{array}$} & \multicolumn{2}{|c|}{$\begin{array}{c}\text { Category II } \\
\text { (abnormal-abnormal) }\end{array}$} & \multicolumn{2}{|c|}{ Total } \\
\hline & & $\begin{array}{l}\text { No (\%) of } \\
\text { cases }\end{array}$ & $\begin{array}{l}\text { No in } \\
\text { category }\end{array}$ & $\begin{array}{l}\text { No (\%) of } \\
\text { cases }\end{array}$ & $\begin{array}{l}\text { No in } \\
\text { category }\end{array}$ & $\begin{array}{l}\text { No (\%) of } \\
\text { cases }\end{array}$ & $\begin{array}{l}\text { No in } \\
\text { category }\end{array}$ & $\begin{array}{l}\text { No (\%) of } \\
\text { cases }\end{array}$ & $\begin{array}{l}\text { No in all } \\
\text { categories }\end{array}$ \\
\hline ongenital defect not affecting central nervous system & $\begin{array}{lll}\cdots & \cdots & \cdots\end{array}$ & $\ldots 17$ (4) & 449 & $21(7)$ & 289 & $25(13)$ & 194 & $63(7)$ & 932 \\
\hline 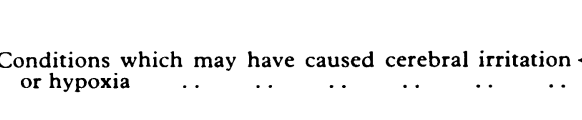 & $\begin{array}{l}\text { Neonatal hypoxia } \\
\text { Hypoglycaemia } \\
\text { Meningitis } \\
\text { Febrile convulsions } \\
\text { Other }\end{array}$ & $\begin{array}{l}9(2) \\
5(1) \\
2(<1) \\
63(14) \\
30(6)\end{array}$ & 465 & $\begin{array}{rr}8 & (3) \\
4 & (1) \\
0 & (0) \\
14 & (5) \\
25 & (8)\end{array}$ & 296 & $\begin{array}{rr}18 & (8) \\
4 & (2) \\
2 & (1) \\
6 & (3) \\
47 & (22)\end{array}$ & 209 & $\begin{array}{c}35(3) \\
13(1) \\
4(<1) \\
83(9) \\
102(11)\end{array}$ & 970 \\
\hline Transient neurological problem in first month of life & . $\quad \ldots$ & . 15 (3) & 457 & $15(5)$ & 291 & $23(12)$ & 200 & $53(6)$ & 948 \\
\hline
\end{tabular}

*Total number of cases in each category varies according to number of children for whom information on each factor was available.

PRODROMAL ILLNESSES

Table III lists the numbers of children with a history of certain infectious diseases within four weeks before admission to hospital. The diseases were selected because they are sometimes associated with postinfectious encephalitis. In each of categories IA and IB some $10 \%$ of children had recently had one of the infections. Seventeen previously normal children had had recent pertussis infection. A year later one of these had died, one had severe neurological sequelae, and one had mild speech delay. The remaining 14 were normal.

Table IV shows the children with an infection present on admission. Upper respiratory tract infections were present in 246 cases. An additional 50 children had otitis media. Gastroenteritis and diarrhoea were most common in category IB.

\section{PAST HISTORY}

Children in category II (abnormal-abnormal) were those with a past history of congenital defect affecting the central nervous system, non-febrile convulsions, a neurological problem persistent beyond the first month of life, or retarded development. Table $\mathrm{V}$ shows the

TABLE VI-Diagnosis or impression 15 days after admission or on discharge

\begin{tabular}{|c|c|c|c|c|c|c|c|c|}
\hline \multirow{3}{*}{$\begin{array}{l}\text { Clinicians' } \\
\text { diagnosis or } \\
\text { impression }\end{array}$} & \multicolumn{6}{|c|}{ Category } & & \\
\hline & \multicolumn{2}{|c|}{$\begin{array}{l}\text { IA } \\
\text { (normal- } \\
\text { normal) }\end{array}$} & \multicolumn{2}{|c|}{$\begin{array}{c}\text { IB } \\
\text { (normal- } \\
\text { abnormal) }\end{array}$} & \multicolumn{2}{|c|}{$\begin{array}{c}\text { II } \\
\text { (abnormal- } \\
\text { abnormal) }\end{array}$} & \multicolumn{2}{|c|}{ Total } \\
\hline & No & $\%$ & No & $\%$ & No & $\%$ & No & $\%$ \\
\hline \multicolumn{9}{|l|}{$\begin{array}{l}\text { (Myelo) ence- } \\
\text { phalitis/ }\end{array}$} \\
\hline & 50 & 10 & 86 & 28 & 23 & 11 & 159 & 16 \\
\hline $\begin{array}{l}\text { Viral encephalitis } \\
\text { Febrile con- } \\
\text { vulsions }(30 \mathrm{~min}\end{array}$ & 44 & 9 & 64 & 20 & 8 & 4 & 116 & 12 \\
\hline $\begin{array}{l}\text { vulsions (30 min } \\
\text { plus) } \\
\text { Prolonged non- }\end{array}$ & 264 & 56 & 22 & 7 & 30 & 14 & 316 & 32 \\
\hline $\begin{array}{l}\text { febrile con- } \\
\text { vulsions }\end{array}$ & 43 & 9 & 18 & 6 & 22 & 10 & 83 & 8 \\
\hline Epilepsy .. $\quad .$. & 13 & 3 & 4 & 1 & 27 & 13 & 44 & 4 \\
\hline Infantile spasms & 48 & 10 & 68 & 22 & 96 & 46. & 212 & 21 \\
\hline Reye's syndrome & 8 & 2 & 32 & 10 & 2 & 1 & 42 & 4 \\
\hline Other $\ldots$ & 7 & 1 & 18 & 6 & 3 & 1 & 28 & 3 \\
\hline Total & 477 & 100 & 312 & 100 & 211 & 100 & 1000 & 100 \\
\hline
\end{tabular}

children in all three categories who gave a past history of other clinical problems that might affect susceptibility to neurological illness.

\section{CLINICAL DIAGNOSIS}

Table VI gives the clinicians' diagnosis or impression 15 days after admission or on discharge or death. Infantile spasms were diagnosed in over one-fifth of cases, including 96 children (46\%) in category II, $68(22 \%)$ in category IB, and $48(10 \%)$ in category IA. In category IA, 264 children ( $56 \%$ ) had prolonged febrile convulsions. Apart from infantile spasms, the major diagnostic groups in category IB were (myelo) encephalitis/encephalopathy (86 cases; $28 \%$ ) and viral encephalitis $(64 ; 20 \%)$, and in category II prolonged afebrile convulsions (22 cases; 10\%) and epilepsy (27;13\%).

\section{HISTORY OF IMMUNISATION}

Diphtheria, tetanus, and pertussis vaccine-Thirty-five of the notified children $(3.5 \%)$ and 34 controls $(1.7 \%)$ had been immunised with diphtheria, tetanus, and pertussis vaccine within the seven days before the date of onset of the neurological illness (or the date on which the controls were the same age) (table VII). The relative risk of neurological illness in immunised as compared with unimmunised children (table VIII) was $2 \cdot 4(p<0.001)$. Twenty of the notified children $(2.0 \%)$ and 18 controls $(0.9 \%)$ had been immunised within 72 hours, with a relative risk of $2.6(p<0.01)$. Thus significantly more notified infants than controls had been immunised during the seven days-and especially the 72 hours-before the onset of the neurological disorders. When the analysis was confined to children apparently previously normal, the differences were larger and the relative risks higher.

Diphtheria and tetanus vaccine-No significant association was found (at the $5 \%$ level) between serious neurological illness and preceding immunisation with diphtheria and tetanus vaccine (table VIII).

\section{CONFOUNDING VARIABLES}

Case-control studies have the disadvantage that unmatched factors may influence the controls' chance of exposure to the risk

\begin{tabular}{|c|c|c|c|c|c|c|}
\hline & & \multicolumn{3}{|c|}{$\begin{array}{l}\text { Delay from immunisation to onset of neurological } \\
\text { illness (days) }\end{array}$} & \multirow{2}{*}{$\begin{array}{l}\text { Not immunised } \\
\text { within } 14 \text { days }\end{array}$} & \multirow[b]{2}{*}{ Total } \\
\hline & & $0-3$ & $4-7$ & $8-14$ & & \\
\hline & & No $\%$ & No \% & No $\%$ & No $\%$ & No $\%$ \\
\hline Diphtheria, tetanus, and pertussis vaccine \{ & $\left\{\begin{array}{l}\text { All cases } \\
\text { Controls } \\
\text { Previously normal cases } \\
\text { Controls }\end{array}\right.$ & $\begin{array}{ll}20 & 2 \cdot 0 \\
18 & 0 \cdot 9 \\
19 & 2 \cdot 4 \\
12 & 0 \cdot 8\end{array}$ & $\begin{array}{ll}15 & 1 \cdot 5 \\
16 & 0 \cdot 8 \\
13 & 1 \cdot 7 \\
13 & 0 \cdot 8\end{array}$ & $\begin{array}{rr}12 & 1 \cdot 2 \\
29 & 1 \cdot 5 \\
9 & 1 \cdot 2 \\
23 & 1 \cdot 5\end{array}$ & $\begin{array}{r}4095 \cdot 2 \\
189296 \cdot 8 \\
73994 \cdot 7 \\
149796 \cdot 9\end{array}$ & $\begin{array}{rl}987 & 100 \\
1955 & 100 \\
780 & 100 \\
1545 & 100\end{array}$ \\
\hline Diphtheria and tetanus vaccine & $\left\{\begin{array}{l}\text { All cases } \\
\text { Controls } \\
\text { Previously normal cases } \\
\text { Controls }\end{array}\right.$ & $\begin{array}{rl}8 & 0 \cdot 8 \\
10 & 0 \cdot 5 \\
5 & 0 \cdot 8 \\
7 & 0 \cdot 4\end{array}$ & $\begin{array}{rr}12 & 1 \cdot 2 \\
14 & 0 \cdot 7 \\
10 & 1 \cdot 3 \\
9 & 0 \cdot 6\end{array}$ & $\begin{array}{rr}11 & 1 \cdot 1 \\
32 & 1 \cdot 6 \\
9 & 1 \cdot 2 \\
24 & 1 \cdot 6\end{array}$ & $\begin{array}{r}95696 \cdot 8 \\
189997 \cdot 2 \\
75696 \cdot 9 \\
150597 \cdot 4\end{array}$ & $\begin{array}{rl}987 & 100 \\
1955 & 100 \\
780 & 100 \\
1545 & 100\end{array}$ \\
\hline
\end{tabular}


factor under investigation and therefore bias the results. Such factors include a past history of fits and social class.

History of fits-A past history of fits is a recommended contraindication to immunisation with diphtheria, tetanus, and pertussis vaccine. Including such cases may lead to an underestimate of the relative risk. A separate calculation limited to previously normal children with no past history of fits gave a relative risk of 3.2 for immunisation with the vaccine within 72 hours (compared with $2 \cdot 1$ for all previously normal cases).

Social class-Immunisation acceptance rates are lowest among manual classes.? Controls could not be matched for this variable, and the effects of social-class differences were assessed by confining

\section{Discussion}

Most of the children notified to the study with serious neurological disorders had not received any immunisation ${ }_{c}$ within seven days of their first symptoms, and their illnessesmust be attributed to other causes. There was, however, a statistically significant association with diphtheria, tetanus, and pertussis vaccine given within the previous seven days, andळ especially within 72 hours. Similar analysis for diphtheria andm tetanus vaccine showed a slight excess of immunisation within? seven days but the relative risk was not significant at the $5 \%$

TABLE VIII-Relative risks* of serious neurological illness after immunisation

\begin{tabular}{|c|c|c|c|}
\hline & \multicolumn{3}{|c|}{ Time from immunisation to onset of illness (days) } \\
\hline & $0-7$ & $0-3$ & $4-7$ \\
\hline Diphtheria, tetanus, and pertussis vaccine..$\left\{\begin{array}{l}\text { All cases } \\
\text { Previously normal cases }\end{array}\right.$ & $\begin{array}{l}2.4(\mathrm{p}<0.001) \\
3.3(\mathrm{p}<0.001)\end{array}$ & $\begin{array}{l}2.6(\mathrm{p}<0.01) \\
4.2(\mathrm{p}<0.001)\end{array}$ & $\begin{array}{l}2.0(0.05<p<0.1) \\
2 \cdot 1(0.05<p<0.1)\end{array}$ \\
\hline Diphtheria and tetanus vaccine $\quad \ldots \quad \ldots\left\{\begin{array}{l}\text { All cases } \\
\text { Previously normal cases }\end{array}\right.$ & $\begin{array}{l}1.5(\mathrm{p}>0.2) \\
1.8(0.05<\mathrm{p}<0.1)\end{array}$ & $\begin{array}{l}1.6(p>0.2) \\
1.7(p>0.2)\end{array}$ & $\begin{array}{l}1.4(p>0.2) \\
1.8(p>0.2)\end{array}$ \\
\hline
\end{tabular}

*Calculated according to the method of Miettinen. ${ }^{11}$

TABLE IX-Clinical details of 11 previously normal children immunised with diphtheria, tetanus, and pertussis vaccine within seven days before onset of illness and reported to be abnormal at least one year later

\begin{tabular}{|c|c|c|}
\hline Case No & Diagnosis & Late outcome \\
\hline 1 & Prolonged convulsion & Minor delay in speech/social \\
\hline $\begin{array}{l}2 \\
3 \\
4 \\
5\end{array}$ & $\begin{array}{l}\text { Prolonged convulsion } \\
\text { Encephalitis/encephalopathy } \\
\text { Encephalitis/encephalopathy } \\
\text { Encephalitis/encephalopathy }\end{array}$ & $\begin{array}{l}\text { Major delay in global development } \\
\text { Major delay in global development } \\
\text { Minor delay in global development } \\
\text { Major delay in global develop- } \\
\text { ment and hemiplegia }\end{array}$ \\
\hline 6 & $\begin{array}{l}\text { Encephalitis/encephalopathy } \\
\text { (Coxsackie B5 virus in } \\
\text { cerebrospinal fluid) }\end{array}$ & $\begin{array}{l}\text { Major delay in global development, } \\
\text { and blind }\end{array}$ \\
\hline 7 & Encephalitis/encephalopathy & Dead \\
\hline $\begin{array}{l}8 \\
9\end{array}$ & $\begin{array}{l}\text { Infantile spasms } \\
\text { Infantile spasms }\end{array}$ & $\begin{array}{l}\text { Minor delay in speech development } \\
\text { Minor delay in motor/speech/ } \\
\text { social development, major delay } \\
\text { in manipulation development }\end{array}$ \\
\hline $\begin{array}{l}10 \\
11\end{array}$ & $\begin{array}{l}\text { Infantile spasms } \\
\text { Reye's syndrome }\end{array}$ & $\begin{array}{l}\text { Major delay in global development } \\
\text { Dead }\end{array}$ \\
\hline
\end{tabular}

the calculation of relative risk to those pairs of children in which both the affected child and at least one of the controls were of the same social class. Nn major differences were noted from the risks calculated for the whole study ponulation.

\section{CLINICAL DIAGNOSIS AND LATE OUTCOME OF VACCINE-ASSOCIATED CASES}

Diphtheria, tetanus, and pertussis vaccine--Thirty-five children had been immunised with the triple vaccine within seven days of onset of the neurological illness. Twenty were in category IA (normalnormal). Twelve had convulsions alone, four had encephalopathy, three had infantile spasms, and one had acute infantile hemiplegia. At final follow-up at least one year later 18 were normal, one had minor delay in speech development, and one had a major delay in global development. Of the 12 children in category IB, two had prolonged convulsions, six had encephalitis/encephalopathy, three had infantile spasms, and one had Reye's syndrome. At final follow-up three children were regarded as normal, seven showed varying degrees of developmental retardation, and two had died. Two children had an alternative explanation for their neurological condition. The three children in category II had prolonged convulsions. One child had a history of birth asphyxia and cerebral palsy, another had agenesis of the corpus callosum, and the third had shown retarded development from birth. Table IX gives the clinical details of all 11 children reported as abnormal one year or more after immunisation with the triple vaccine. It must be emphasised that the abnormalities in these children cannot necessarily be ascribed to pertussis immunisation. level. These calculations were made without excluding cases ${ }^{\circ}$ with evidence of other possible causes, such as viral illnessese or late-presenting congenital abnormalities such as tuberous sclerosis, and thus may overestimate the risks. We conclude 5 that serious neurological reactions after immunisation with the triple vaccine are very rare and most of the vaccine-associated cases showed no evidence of residual damage one year later.

\section{CAUSE VERSUS ASSOCIATION}

Finding a statistically significant association between two independent variables at the $5 \%$ level does not necessarilyo imply that one event caused the other. Other evidence which would support a causal association would be that the illnesses are (a) clinically distinctive, $(b)$ restricted to immunised children $\overrightarrow{\vec{D}}$ (c) closely related in time to immunisation, $(d)$ associated with a biologically plausible pathogenesis, and $(e)$ without alternative explanation. In the case of the triple vaccine and serious? neurological illnesses only some of these criteria were satisfied.

The range of neurological illnesses found in cases associated with the triple vaccine was clinically indistinguishable from that occurring in unimmunised children or in cases associated with the diphtheria and tetanus vaccine. This finding does noi support Stewart's concept of a "pertussis reaction syndrome." 3 A close time relation was found between the onset of illness and preceding immunisation with diphtheria, tetanus, and pertussis vaccine. The mechanism for pertussis-vaccine-associateds neurological disease remains obscure: it may either be cause of by a direct neurotoxic effect or be mediated indirectly via. immune mechanisms. ${ }^{8}$ Finally, an alternative aetiology for the 0 neurological illness was suggested in some of the cases.

\section{ATTRIBUTABLE RISK}

The attributable risk ${ }^{9}$ is that part of the incidence of a diseaseo which can be attributed to a particular causal agent and $\overrightarrow{\mathrm{P}}$ represents the difference between the incidence of the condition (serious neurological disorders) in exposed (immunised) ${ }_{\Omega}^{\mathbb{D}}$ subjects and that in non-exposed (unimmunised) subjects. It cano usually be calculated only from a cohort study. The present study, however, covered an entire national population, so thaf the number of serious neurological illnesses notified shoulds. in theory represent the total incidence of such conditions ir the population. By making further assumptions about the 
exposure of the population to immunisation, estimates of attributable risk may be calculated. Nevertheless, because of the broad nature of these assumptions and the wide confidence limits the derived risk figures must be interpreted with extreme caution and cannot be regarded as precise measures.

The estimated attributable risk of serious neurological disorders occurring within seven days after immunisation with diphtheria, tetanus, and pertussis vaccine in previously normal children irrespective of outcome is one in 110000 injections ( $95 \%$ confidence limits, one in 360000 to one in 44000 ). The corresponding rate for previously normal children with neurological sequelae persistent one year later is one in 310000 injections (95\% confidence limits, one in 5310000 to one in $54000)$. These estimates include all vaccine-associated cases without excluding any with a possible alternative explanation.

The risk figures derived by the study must be set against the dangers of pertussis disease. Though 17 previously normal children had had pertussis, of whom three had sequelae, the age range covered by the study does not include the complete incidence of the disease. If, however, estimates of the risks of pertussis can be obtained from other sources, those in conjunction with the present results should allow a valid judgment to be made about pertussis immunisation policy.

This paper is an abbreviated version of a report on the National Childhood Encephalopathy Study submitted to the Department of Health and Social Security. ${ }^{10}$

We acknowledge with gratitude the willing co-operation and consent of doctors in hospitals, general practices, and community health services throughout Britain who let us study patients in their care. We are also indebted to the many health visitors who completed most of the home questionnaires and the parents of notified and control children who allowed us to visit them. We are grateful to the members of the study team, in particular to Drs D R Coid, A F Froley, P D Poore, and M Spencely and to Mrs D Car, Mr R Dewar, Miss S Grisedale, and Miss M J Parker for their help and to Professors P Armitage, J A Dudgeon, R W Gilliatt, Sir Charles Stuart-Harris, and $S T$ Winter for encouragement and advice. The study was financed by a grant from the Department of Health and Social Security.

\section{References}

${ }^{1}$ Madsen $\mathrm{T}$. Vaccination against whooping cough. $\mathcal{F} A M A$ 1933;101:187-8.

2 Kulenkampff M, Schwartzman JS, Wilson J. Neurological complications of pertussis inoculation. Arch Dis Child $1974 ; 49: 46-9$.

${ }^{3}$ Stewart GT. Vaccination against whooping cough. Efficacy versus risks. Lancet 1977 ; : $234-7$.

4 Swansea Research Unit of the Royal College of General Practitioners. Effect of a low pertussis vaccination uptake on a large community. Br Med F 1981 ;282:23-6.

5 Prensky AL. Pertussis vaccination. Dev Med Child Neurol 1974;16:539-43.

6 Rawson NSB, Alderslade R, Miller DL. Discrepancies in immunization records. Community Med 1980;2:202-8.

${ }^{7}$ Davie R, Butler N, Goldstein H. From birth to seven. London: Longman, 1972:59-70.

${ }^{8}$ Ross EM, Bellman MH. Encephalitis and encephalopathy. In: Rose FC, ed. Paediatric neurology. Oxford: Blackwell, 1979:552-68.

Barker DJP, Rose G. Epidemiology in medical practice. Edinburgh: Churchill Livingstone, 1976.

10 Department of Health and Social Security. Whooping cough: reports from the Committee on Safety of Medicines and the foint Committee on Vaccination and Immunisation. London: HMSO, 1981.

${ }^{11}$ Miettinen OS. Estimation of relative risk from individually matched series. Biometrics $1970 ; 26: 75-86$.

(Accepted 30 March 1981)
What investigations are advised for an 11-year-old apparently normal boy who is greatly undersized? His parents and sisters are of normal size.

A thorough physical examination should show whether this boy is otherwise in good health. Particular pitfalls to be avoided are occult gastrointestinal disease, undertreated asthma, and psychological problems. These will all tend to make the boy strikingly thin. If he is otherwise normal no investigations should be done until he has been shown not to be growing at a normal rate. If two measurements made by the same person on the same equipment show that the height has not increased by at least $2 \mathrm{~cm}$ in a six-month period an endocrine (or other) abnormality should be considered. This will probably entail investigation in hospital with a view to excluding pituitary problems, hypothyroidism, and other causes of short stature with a low-growth velocity.

If the boy is growing at a normal rate his history may explain his present size. Nevertheless, nothing can now be done to improve his final height, which will be predicted by measuring the skeletal maturity, which will indicate how long growth will continue. Measurement of skeletal maturity does not generally help in making an organic diagnosis. If the bone age is greatly delayed and growth will continue for a very long time it may be permissible to contemplate treatment to shorten the growing period, but this will not increase final height. Such treatment with androgenic hormones can lead to a reduction in adult height achieved (if large doses are used) and the decision to treat is difficult.

The combination of ephedrine, theophylline, and phenobarbitone is used for treating asthma. Does this combination have any particular side effects that the patient should be warned about ?

In general, prescription of medicines containing more than one drug should be avoided. An increased number of adverse effects are likely, and the causative drug may be difficult to identify or even be overoverlooked if the medicine is not recognised to contain several drugs. Also, there is a greater likelihood of interactions with other drugs taken by the patient. Theophylline is an effective bronchodilator and the oral dose should be titrated to give a plasma concentration of 10-20 $\mathrm{mg} / \mathrm{l}$ for maximum therapeutic effect. Since some patients require large oral doses to achieve this, considerable ingestion of the other drugs, phenobarbitone and ephedrine, will occur. As a result the patient may experience drowsiness related to the phenobarbitone, and urinary retention, cardiac arrhythmias, psychoses, and nasal obstruction due to the sympathomimetic drug ephedrine. Phenobarbitone is a potent inducer of hepatic enzymes but is thought to increase the metabolism of theophylline-that is, diminish the therapeutic effect at given doses-in only a few patients. The phenobarbitone, however, may interfere with the plasma binding and metabolism of other drugs given at the same time. If the therapeutic plasma range for theophylline is exceeded toxic effects may be seen-for instance, agitation, confusion, convulsions, nausea, vomiting, and other gastrointestinal effects.

$A$ patient with severe rheumatoid arthritis fractured her right tibia and fibula after a relatively slight injury. Radiography confirmed the diagnosis but also showed pronounced osteoporosis of the bones. Should this osteoporosis be treated with, say, calcium lactate and vitamin $D$ or is there any other treatment?

Rheumatoid arthritis is associated with osteoporosis on three counts. Firstly, the disease itself probably leads to mild bone loss, this effect being most pronounced in postmenopausal women; secondly, prolonged steroid treatment leads to pronounced osteoporosis in al age groups, and, finally, bed rest is associated with bone loss. Furthermore, many arthritic patients develop vitamin $\mathrm{D}$ deficiency and osteomalacia because they are not exposed to much sunlight. ${ }^{1}$ In the housebound, particularly, vitamin D replenishment in "physiological" doses-for example, 500 IU daily as a calcium and vitamin D tablet $B P C$ that must be chewed-may help to avoid the tragedy of a major fracture. Steroids endanger the skeleton but if their administration is unavoidable they should be given on alternate days. In postmenopausal women the diet should contain at least 1-2 g elemental calcium, and further supplementation of calcium with or without low-dose hormone-replacement therapy-for example, $5-10 \mu \mathrm{g}$ of ethinyloestradiol daily three weeks out of four-may be considered.

${ }^{1}$ O'Driscoll S, O'Driscoll M. Osteomalacia in rheumatoid arthritis. Ann Rheum Dis $1980 ; 39: 1-6$. 